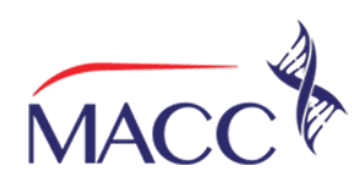

\title{
Hubungan Neutrophil - Lymphocyte Ratio (NLR) Terhadap Mortalitas Pasien Sepsis di Unit Perawatan Intensif RSUP Haji Adam Malik Pada Tahun 2018

\author{
Bastian Lubis ${ }^{1 *}$, Ahmad Yapiz Hasby ${ }^{1}$, Alvin Oktomy Putra ${ }^{1,}$, Gema Nazri \\ Yanni², Putri Amelia²
}

1. Departemen Anestesiologi dan Terapi Intensif, Fakultas Kedokteran, Universitas Sumatera Utara

2. Departemen Pediatri, Fakultas Kedokteran, Universitas Sumatera Utara

\begin{abstract}
ABSTRAK
Sepsis adalah keadaan disfungsi organ yang mengancam jiwa yang disebabkan karena disregulasi respons tubuh terhadap infeksi. Sepsis juga merupakan penyebab kematian utama di antara pasien kritis unit perawatan intensif non-koroner di Amerika Serikat. Salah satu biomarker yang digunakan adalah neutrophil-lymphocyte ratio (NLR). Sampai saat ini masih belum digelar konsensus untuk melihat hubungan antara NLR dengan prognosis pasien sepsis. Tujuan penelitian ini untuk melihat hubungan NLR terhadap mortalitas pasien sepsis di ICU RSUP Haji Adam Malik. Penelitian ini merupakan penelitian analitik dengan desain penelitian berupa cross-sectional. Data penelitian ini menggunakan data sekunder berupa rekam medis dan metode pengumpulan data berupa total sampling. Dari hasil penelitian, didapatkan insidensi sepsis di ICU (termasuk CVCU) Rumah Sakit Umum Pusat (RSUP) Haji Adam Malik pada tahun 2018 sebanyak 97 pasien dan didominasi oleh pasien lansia ( $>45$ tahun) sebanyak 58 orang. Hasil analisis bivariat uji Fisher's Exact Test didapatkan tidak adanya hubungan yang signifikan secara statistik dengan nilai nilai $p=0,371$ antara NLR terhadap mortalitas pasien sepsis. Tidak didapatkan hubungan NLR terhadap mortalitas pasien sepsis.
\end{abstract}

Kata kunci: Mortalitas, NLR, Sepsis 


\title{
The Correlation Between Neutrophil-Lymphocyte Ratio (NLR)
MACCwards the Mortality of Sepsis Patients in The Intensive Care Unit
of RSUP Haji Adam Malik in 2018
}

\author{
Bastian Lubis ${ }^{1 *}$, Ahmad Yapiz Hasby ${ }^{1}$, Alvin Oktomy Putra ${ }^{1,}$, Gema Nazri \\ Yanni², Putri Amelia ${ }^{2}$
}

1. Anaesthesiology and Intensive Therapy Department, Faculty of Medicine, Universitas Sumatera Utara

2. Pediatric Department, Faculty of Medicine, Universitas Sumatera Utara

*corresponding author

\begin{abstract}
Background: Gastrointestinal endoscopy is a procedure to evaluate various gastrointestinal Sepsis is a life-threathening organ dysfunction caused by dysregulation of the body's responsse to infection. Sepsis is also a leading cause of death among critically ill patients in non - coronary intensive care units in the United States. To evaluate how severe an inflammation is, biomarker is used. One of them is neutrophil - lymphocyte ratio (NLR). Until today, the consensus to see the correlation between NLR and prognosis of sepsis patients has not been held. For that reason, the NLR value of sepsis patients is still a controversy and needs further investigation. The goal of this study is to see the correlation between NLR towards the mortality of sepsis patient the intensive care unit of RSUP Haji Adam Malik. This is an analytic study with cross -sectional design. The data used in this study is secondary data such as medical records and collected using total sampling method. The total incidence of sepsis in ICU (including CVCU) of RSUP Haji Adam Malik in 2018 is 97 patients and it is dominated by the elderly (> 45 years old) with a total of 58 people and men (58 people). The result of the bivariate analysis using Fisher's Exact test resulted in showing no significant correlation between NLR towards the mortality of sepsis patient with $p$ value of 0.371 . There is no correlation between NLR towards mortality of sepsis patient.
\end{abstract}

Key words: Mortality, NLR, Sepsis 


\section{PENDAHULUAN}

Sepsis adalah keadaan disfungsi organ yang mengancam jiwa yang disebabkan karena disregulasi respons tubuh terhadap infeksi. ${ }^{1}$ Sepsis juga merupakan penyebab kematian utama di Amerika Serikat terutama diantara pasien kritis di unit perawatan intensif nonkoroner. ${ }^{2}$ Berdasarkan buletin yang diterbitkan oleh World Health Organization (WHO) pada tahun 2010 yang dikutip oleh sebuah penelitian tahun 2018, setiap tahunnya terjadi 750.000 kasus sepsis di Amerika Serikat. ${ }^{3}$ Insidensi sepsis di Indonesia tidak tercatat secara pasti, namun menurut beberapa rumah sakit rujukan, prevalensi sepsis berkisar 15\%-37,2\% pada pasien rawat intensif dengan derajat mortalitas sebesar 37\%-80\%. Pada tahun 2010, tercatat bahwa prevalensi pasien rawat intrnsif yang menderita sepsis di Rumah Sakit Dr. Cipto Mangunkusumo adalah 25\% dengan derajat mortalitas sebesar 77,3\%. ${ }^{4}$

Biomarker mempunyai peranan penting dalam proses ini karena dapat mengindikasikan ada atau tidaknya sepsis, derajat keparahan sepsis, serta membedakan infeksi yang disebabkan oleh bakteri, virus ataupun jamur. Fungsi potensial lain biomarker termasuk didalamnya untuk menentukan prognosis, menentukan terapi antibiotik yang akan digunakan, mengevaluasi responss pasien sepsis terhadap terapi, membedakan mikroorganisme penyebab sepsis (gram positif atau gram negatif), memprediksi komplikasi ataupun terjadinya disfungsi organ pada pasien sepsis. Namun, peran biomarker dalam tatalaksana sepsis masih belum dapat ditentukan secara pasti. ${ }^{5}$

Neutrophil - lymphocyte ratio (NLR), salah satu biomarker yang mudah untuk diakses dan dapat dihitung dengan adanya pemeriksaan darah lengkap, pertama kali digunakan sebagai biomarker tambahan dalam menilai respons inflamasi secara klinis pada tahun 2001. Sampai saat ini, belum digelar konsensus untuk melihat hubungan antara NLR dengan prognosis pasien sepsis. Menurut sebuah penelitian tahun 2015 oleh Riche dkk. menunjukkan adanya perubahan NLR secara terbalik dimana pada pasien sepsis yang mengalami early death $(<5$ hari) kadar NLR lebih rendah dibandingkan pasien yang mengalami late death ( $>5$ hari). ${ }^{6}$ Namun, ada juga penelitian yang menyatakan bahwa nilai NLR tidak berhubungan dengan mortalitas pasien sepsis. Oleh karena itu, fungsi NLR secara klinis pada pasien sepsis masih merupakan suatu kontroversi dan membutuhkan investigasi lebih lanjut. ${ }^{7}$

\section{METODOLOGI PENELITIAN}

Jenis penelitian yang digunakan pada penelitian ini adalah analitik dengan desain potong lintang. Penelitian ini dilakukan dengan menggunakan data sekunder melalui data rekam medis penderita sepsis di ICU RSUP Haji Adam Malik. Penelitian ini dilaksanakan di RSUP Haji Adam Malik Medan dan dilaksanakan pada JuliDesember 2019.

Sampel penelitian yang digunakan adalah seluruh rekam medis pasien sepsis yang tercatat di ICU RSUP Haji Adam Malik dari 1 Januari 201831 Desember 2018 dengan teknik pengambilan sampel berupa total sampling dengan kriteria inklusi berupa pasien yang berusia $\geq 18$ tahun serta memiliki hasil perhitungan jenis leukosit. Kemudian data dianalisa menggunakan software analisis berupa SPSS dengan metode analisa bivariat, yaitu fisher exact test.

\section{HASIL PENELITIAN}

Jumlah pasien sepsis di RSUP Haji Adam Malik Medan periode 1 Januari - 31 Desember 2018 adalah sebanyak 457 pasien. Sampel yang memenuhi kriteria inklusi penelitian ini adalah 90 orang dari total 97 orang yang di rawat di ICU (termasuk CVCU) RSUP Haji Adam Malik. Insidensi sepsis di unit perawatan intensif RSUP Haji Adam Malik periode 1 Januari-31 Desember 2018 didominasi pasien dengan jenis kelamin laki-laki sebanyak 58 orang dengan persentase sebesar $64,4 \%$, sedangkan untuk jenis kelamin perempuan didapatkan jumlah sampel sebanyak 32 orang dengan persentase sebesar 35,6\%. Untuk perbedaan nilai NLR antara kedua jenis kelamin, didapatkan median nilai NLR pada jenis kelamin laki-laki sebesar 15,18 , sedangkan pada jenis kelamin perempuan didapatkan median nilai NLR sebesar 11,20. Pada penelitian ini didapatkan median kadar neutrofil yang lebih tinggi pada pria yaitu sebesar 14,76 dan kadar limfosit yang lebih tinggi pada wanita yaitu sebesar 1,11. 
Tabel 1. Karakteristik Subjek Penelitian

\begin{tabular}{|c|c|}
\hline Variabel & $n(\%)=90$ \\
\hline \multicolumn{2}{|l|}{ Kelompok Usia } \\
\hline Dewasa (18 - 45) & $32(35,6)$ \\
\hline Lanjut usia $(>45)^{* *}$ & $58(64,4)$ \\
\hline \multicolumn{2}{|l|}{ Jenis Kelamin } \\
\hline Laki-laki & $58(64,4)$ \\
\hline Perempuan & $32(35,6)$ \\
\hline Neutrofil* & $14,27(1,40-65,02)$ \\
\hline \multicolumn{2}{|l|}{ Nilai neutrofil berdasarkan jenis kelamin* } \\
\hline Laki-laki & $14,76(1,40-44,08)$ \\
\hline Perempuan & $13,38(1,72-65,02)$ \\
\hline \multicolumn{2}{|l|}{ Nilai neutrofil berdasarkan kelompok usia* } \\
\hline Dewasa & $114,20(1,66-65,02)$ \\
\hline Lanjut usia** & $14,27(1,40-63,46)$ \\
\hline Limfosit & $1,01(0,08-12,76)$ \\
\hline \multicolumn{2}{|l|}{ Nilai limfosit berdasarkan jenis kelamin } \\
\hline Laki-laki & $1,02(0,08-12,76)$ \\
\hline Perempuan & $1,11(0,22-9,77)$ \\
\hline \multicolumn{2}{|l|}{ Nilai limfosit berdasarkan kelompok usia } \\
\hline Dewasa & $50(50,5 \%)$ \\
\hline Lanjut usia** & $25(49 \%)$ \\
\hline NLR* & $14,14(1,00-105,76)$ \\
\hline \multicolumn{2}{|l|}{ Nilai NLR berdasarkan jenis kelamin* } \\
\hline Laki-laki & $15,18(1,003-72)$ \\
\hline Perempuan & $11,20(1,15-105,76)$ \\
\hline \multicolumn{2}{|l|}{ Nilau NLR berdasarkan kelompok usia* } \\
\hline Dewasa & $13,26(1,003-72)$ \\
\hline Lanjut usia** & $15,63(2,18-105,76)$ \\
\hline
\end{tabular}

*Digunakan median (min - max) dikarenakan data tidak berdistribusi normal

**Cut off usia lansia berdasarkan Depkes RI 2009 yang menyatakan bahwa lansia dimulai dari lansia awal yaitu usia 46 tahun- 55 tahun, dilanjutkan lansia akhir dari usia 56 - 65 tahun dan manula untuk $>65$ tahun.

Hasil analisis dianggap bermakna bila nilai berdasarkan kelompok usia, didapatkan hasil bahwa insidensi sepsis di unit perawatan intensif RSUP Haji Adam Malik periode 1 Januari - 31 Desember 
2018 didominasi oleh lanjut usia dengan jumlah sampel sebanyak 58 orang dengan persentase sebesar $64,4 \%$, sedangkan untuk kelompok usia dewasa didapatkan sampel sebanyak 32 orang dengan persentase sebesar $35,6 \%$. Untuk perbedaan nilai NLR berdasarkan kelompok usia, didapatkan median nilai NLR pada kelompok umur lanjut usia sebesar 15,63 , sedangkan pada kelompok usia dewasa didapatkan median nilai NLR sebesar 13,26. Pada penelitian ini didapatkan kadar neutrofil yang lebih tinggi pada lanjut usia yaitu sebesar 14,27 dan kadar limfosit yang lebih tinggi pada dewasa yaitu sebesar 1,42 (Tabel 1). Mayoritas pasien sepsis dengan kadar NLR yang tinggi pada saat pertama kali ke ICU mengalami early death yaitu sebanyak 41 orang dengan persentase sebesar 45,56\% (Tabel 2). Dikategorikan early death jika kematian terjadi < 5 hari dan late death jika kematian terjadi $>5$ hari. ${ }^{6}$ NLR adalah rasio jumlah neutrofil absolut terhadap jumlah limfosit absolut, ${ }^{8}$ dikategorikan menjadi tinggi atau rendah sesuai dengan cut-off value yaitu 5 , dimana jika $>5$ maka dikategorikan meningkat, dan $<5$ dikategorikan menurun. ${ }^{9}$

\section{PEMBAHASAN}

Distribusi data sepsis dan kadar NLR berdasarkan jenis kelamin menunjukkan hasil bahwa insidensi sepsis didominasi oleh kaum laki - laki dengan persentase sebesar $64,4 \%$. Hal ini sesuai dengan hasil daripenelitian tahun 2014, yang menyatakan bahwa pada saat terjadi sepsis, sistem imun, sitokin serta sel endotel mengalami gangguan dan menyebabkan mikrosirkulasi terganggu sehingga mengakibatkan terjadinya disfungsi organ dan meningkatkan risiko kematian. Pada keadaan seperti ini, hormon seksual laki-laki (misalnya, androgen) memberi efek merusak dikarenakan hormon tersebut bersifat menekan cell- mediated immunity sehingga menyebabkan respons imun terganggu, sedangkan hormon seksual perempuan memberi efek protektif pada saat terjadi keadaan tersebut, sehingga menyebabkan respons imun tidak terganggu dan menurunkan risiko mortalitas. ${ }^{10}$ Kadar NLR pada penelitian ini didapatkan median nilai NLR laki-laki lebih tinggi. Haltersebutberlawananterhadaphasilpenelitian pada suatu populasi yang sehat oleh penelitian tahun 2019, yang menyatakan bahwa nilai NLR berbeda-beda untuk setiap ras, namun untuk ras Asia, selalu didapatkan kadar NLR yang lebih tinggi pada kaum wanita. Walaupun alasannya belum diketahui secara pasti, tetapi ada yang menyatakan bahwa dikarenakan kadar hormon estrogen yang lebih tinggi pada perempuan dibandingkan laki-laki, maka nilai NLR perempuan lebih tinggi dikarenakan hormon estrogen dapat menghambat terjadinya apoptosis sel neutrofil. ${ }^{10}$ Distribusi insidensi sepsis berdasarkan kelompok usia didominasi oleh pasien lanjut usia dengan persentase sebesar $64,4 \%$. Hal ini sesuai dengan penelitian oleh Juneja dkk. tahun 2012, yang menyatakan bahwa insidensi dan prevalensi sepsis menjadi lebih tinggi seiring bertambahnya usia dikarenakan pada lansia sistem imun tubuh mengalami degradasi seiring bertambahnya usia. Patofisiologi terjadinya hal tersebut sangatlah kompleks dan bersifat multifaktorial. Pada lansia, cell - mediated immune system dan

Tabel 2. Hubungan NLR terhadap mortalitas pasien sepsis

\begin{tabular}{|c|c|c|c|}
\hline \multirow{2}{*}{ Kadar NLR } & \multicolumn{2}{|c|}{ Mortalitas } & \multirow{2}{*}{ Nilai P } \\
\hline & Early Death & Late Death & \\
\hline Rendah & $9(10 \%)$ & $4(4,44 \%)$ & \\
\hline Tinggi & $41(45,56 \%)$ & $36(40 \%)$ & 0,371 \\
\hline Total & $50(55,56 \%)$ & $40(44,44 \%)$ & \\
\hline
\end{tabular}


sistem imun humoral mengalami ketidakstabilan secara fungsional dimana organ timus, organ mayor dalam adaptive cell - mediated immune system mengalami atrofi sehingga respons imun yang dihasilkan menjadi terbatas. Selain sel $T$, sel $B$ juga mengalami penurunan seiring bertambahnya usia. Makrofag juga mengalami perubahan fungsi dimana terjadinya penurunan pemrosesan antigen menjadi sel $\mathrm{T}$, menyebabkan aktivitas bakterisidal berkurang. Selain makrofag, sel yang berperan dalam innate immunity seperti neutrofil dan natural killer cells juga mengalami gangguan sehingga sel tersebut menjadi kurang sensitif dalam mengenali dan menghancurkan sel yang telah terinfeksi., ${ }^{9,10}$ Kadar NLR juga dapat dipengaruhi oleh faktor usia, terutama pada wanita, dimana pada wanita lanjut usia didapatkan kadar NLR yang lebih rendah dikarenakan terjadi penurunan kadar estrogen akibat menopause pada populasi sehat. ${ }^{9} \mathrm{Hal}$ ini bertentangan pada penelitian ini dimana didapatkan median kadar NLR yang lebih tinggi pada kelompok lanjut usia. Hasil distribusi silang kadar NLR dengan mortalitas pasien sepsis pada tabel 2 menunjukkan bahwa mayoritas pasien dengan kadar NLR yang tinggi pada saat pertama kali masuk ke ICU mengalami early death, yakni sebesar $45,56 \%$. Setelah dilakukan uji signifikansi menggunakan fisher exact test, didapatkan nilai $p=0,371$ $(p>0,05)$ sehingga dapat disimpulkan bahwa tidak ada hubungan antara kadar NLR terhadap mortalitas pasien sepsis. Hal ini bertentangan dengan hasil yang diperoleh dari penelitian yang dilakukan tahun 2015 dimana mereka menyatakan bahwa kadar NLR yang rendah pada awal masuk di ICU memiliki risiko lebih tinggi untuk mengalami early death karena terjadinya peningkatan kadar limfosit. ${ }^{6}$ Pada pasien sepsis di ICU RSUP Haji Adam Malik, mayoritas pasien mengalami penurunan kadar limfosit absolut disertai peningkatan kadar neutrofil absolut sehingga didapatkan kadar NLR yang cukup tinggi pada pasien sepsis di ICU RSUP Haji Adam Malik. Menurut penelitian 2019, adapun hal-hal yang mempengaruhi kadar NLR selain jenis kelamin dan usia yaitu, suhu. Pada suhu yang dingin, terutama musim dingin, level inflamasi cenderung lebih tinggi karena prevalensi infeksi oleh virus semakin tinggi dan
Hal ini berbeda dengan penelitian oleh Riche et al pada tahun 2015 yang menyatakan bahwa pasien yang mengalami early death mempunyai NLR yang lebih rendah pada awal masuk. Pada penelitian ini tidak didapatkan hubungan antara NLR terhadap mortalitas pasien sepsis di ICU RSUP Haji Adam Malik (nilai $p=>0,05$ ).

biasanya perubahan tersebut lebih tampak pada perempuan, dan indeks massa tubuh (IMT), dimana hal tersebut dapat memengaruhi kadar NLR pada wanita dikarenakan telah diteliti juga sebelumnya dan juga obesitas sering dianggap berhubungan dengan proses inflamasi kronis. ${ }^{10}$ Beberapa studi juga telah menyarankan bahwa NLR dapat menjadi alternatif yang lebih murah dan mudah dalam menentukan reaksi inflamasi dibandingkan dengan $\mathrm{C}$-reactive protein dan sitokin seperti IL-6. Namun menurut penelitian tahun 2013, NLR tidak dapat menggantikan fungsi CRP dan IL-6 secara keseluruhan tetapi hanya sebagai tambahan antar kedua biomarker sehingga dapat disimpulkan bahwa fungsi NLR sebagai penanda inflamasi masih kurang untuk menentukan prognosis pada pasien sepsis. ${ }^{10}$

\section{SIMPULAN}

Dari hasil penelitian ini, adapun kesimpulan yang dapat diambil adalah pasien sepsis di ICU RSUP Haji Adam Malik Medan pada tahun 2018 didominasi oleh laki laki $(64,4 \%)$ dan lanjut usia $(64,4 \%)$ dengan median kadar NLR sebesar 14,14. Pasien sepsis di ICU RSUP Haji Adam Malik yang mengalami early death cenderung mempunyai NLR yang tinggi pada awal masuk.

\section{DAFTAR PUSTAKA}

1. Singer $M$, Deutschman $C S$, Seymour $C$, Shnkar-Hari M, Annane D, Bauer M, et al. The third international consensus definitions for sepsis and septic shock (sepsis-3). JAMA J Am Med Assoc. 2016;315(8):801-10.

2. Mayr FB, Yende S, Angus DC. Epidemiology of severe sepsis. Virulence.2014;5(1):1-11.

3. Irvan I, Febyan F, Suparto S. Sepsis dan Tata Laksana Berdasar Guideline Terbaru. JAI (Jurnal Anestesiol Indones. 2018;10(1):62.

4. Arif SK, Rukka ABS, Wahyuni S. Comparison 
of neutrophils-lymphocytes ratio and procalcitonin parameters in sepsis patient treated in intensive care unit Dr. Wahidin hospital, Makassar, Indonesia. J Med Sci. 2017;17(1):17-21.

5. Pierrakos C, Vincent JL. Sepsis biomarkers: A review. Crit Care.2010;14(1):1-18.

6. Riché $F$, Gayat $E$, Barthélémy $R$, Le Dorze $M$, Matéo J, Payen D. Reversal of neutrophil-tolymphocyte count ratio in early versus late death from septic shock. Crit Care [Internet]. 2015;19(1):1-10. Available from: http:// dx.doi.org/10.1186/s13054-015-1144-x

7. Hwang SY, Shin TG, Jo IJ, Jeon K, Suh GY, Lee $T R$, et al. Neutrophil-to- lymphocyte ratio as a prognostic marker in critically-ill septic patients. Am J Emerg Med [Internet]. 2017;35(2):234-9. Available from: http:// dx.doi.org/10.1016/j.ajem.2016.10.055

8. $\mathrm{Ni} \mathrm{A}$. Reference Values of NeutrophilLymphocyte Ratio, Platelet-Lymphocyte
Ratio and Mean Platelet Volume in Healthy Adults in North Central Nigeria. J Blood Lymph [Internet]. 2016 [cited 2019 Nov 27];6(1). Available from: https://www.omicsgroup.org/journals/ reference-values-of-neutrophillymphocyteratio-plateletlymphocyte-ratio-andmean-platelet-volume-in-healthy-adults-innorth-centra-. php?aid $=68492$

9. Gurol G, Ciftci IH, Terzi HA, Atasoy AR, Ozbek A, Koroglu M. Are There Standardized Cutoff Values for Neutrophil-Lymphocyte Ratios in Bacteremia or Sepsis? Journal of Microbiology and Biotechnology [Internet]. 2015 Apr 28 [cited 2021 Feb 17];25(4):521-5. Available from: http://www.jmb.or.kr/journal/view. html?doi=10.4014/jmb.1408.08060

10. Angele MK, Pratschke S, Hubbard WJ, Chaudry IH. Gender differences in sepsis: Cardiovascular and immunological aspects. Virulence. 2014;5(1):12-9. 